\title{
Influence of Potassium Nutrition and Exogenous Organic Acids on Iron Uptake by Monocot and Dicot Plants
}

\author{
Eman F. A. Awad-Allah* (D), Ibrahim H. Elsokkary \\ Soil and Water Sciences Department, Faculty of Agriculture, Alexandria University, Alexandria, Egypt \\ Email: *eman.awadallah@alexu.edu.eg
}

How to cite this paper: Awad-Allah, E.F.A. and Elsokkary, I.H. (2020) Influence of Potassium Nutrition and Exogenous Organic Acids on Iron Uptake by Monocot and Dicot Plants. Open Journal of Soil Science, 10, 486-500.

https://doi.org/10.4236/ojss.2020.1010025

Received: September 15, 2020

Accepted: October 27, 2020

Published: October 30, 2020

Copyright $\odot 2020$ by author(s) and Scientific Research Publishing Inc. This work is licensed under the Creative Commons Attribution International License (CC BY 4.0).

http://creativecommons.org/licenses/by/4.0/

\begin{abstract}
Iron $(\mathrm{Fe})$ is a vital element for the survival and proliferation of all plants; therefore, Fe-biofortification by the application of chemical and organic fertilizers is being as an effective approach to fight hidden hunger retards the growth and development of crop plants. Two experiments were carried out to investigate the effect of potassium and exogenous organic acids on iron uptake by two different plants: one is monocotyledon, maize (Zea mays L.) and the second is dicotolydon pea (Pisum sativum L.) grown under controlled conditions. The seedlings were grown in sand culture in a greenhouse experiment and irrigated with one-tenth strength modified nutrient solution of Hoagland and Arnon as a base solution ( $\mathrm{pH}$ 7.5), containing different iron treatments $\left(0,1\right.$, and $5 \mathrm{ppm}$ as $\left.\mathrm{FeSO}_{4} \cdot 7 \mathrm{H}_{2} \mathrm{O}\right)$ combined with potassium nutrition $\left(0,5,10\right.$, and $50 \mathrm{ppm}$ as $\left.\mathrm{K}_{2} \mathrm{SO}_{4}\right)$. After 30 days, the best interaction treatment was selected for further experiment including $5.0 \mathrm{ppm} \mathrm{Fe}$ as Fe$\mathrm{SO}_{4} \cdot 7 \mathrm{H}_{2} \mathrm{O}$ and $50 \mathrm{ppm} \mathrm{K}$ as $\mathrm{K}_{2} \mathrm{SO}_{4}$ in combination with $1 \times 10^{-5}$ mole/liter of one of the following organic acids: Citric acid, Oxalic acid, Formic acid, Acetic acid, Propionic acid, Tartaric acid, Succinic acid, Fumaric acid, Malic acid, Glutamic acid, besides the free organic acid nutrient solution as a control. Results revealed that the interaction between $5.0 \mathrm{ppm} \mathrm{Fe}$ and $50 \mathrm{ppm} \mathrm{K}$ was the best interaction treatment for increasing biomass production and iron uptake of maize and pea seedlings under applied condition. Furthermore, exogenous application of organic acids improves uptake and translocation of nutrient such as iron, potassium and phosphorus by the maize and pea plants. In conclusion, potassium nutrition and exogenous organic acids have the potential to stimulate Fe-uptake of monocot and dicot plants and mediate iron-biofortified crops.
\end{abstract}

\section{Keywords}

Potassium, Organic Acids, Iron Uptake, Biofortification, Sustainability 


\section{Introduction}

Iron $(\mathrm{Fe})$ is an essential micronutrient for plants and all other living organisms. It is absorbed by plant roots as $\mathrm{Fe}^{2+}$ and $\mathrm{Fe}^{3+}$ [1] [2]. The chemical properties of Fe make it an important part of oxidation-reduction reactions in both soils and plants [3]. It is a component of a number of proteins and enzymes with proper functioning of metabolic processes related to electron transport, such as respiration and photosynthesis, and for chlorophyll biosynthesis [2] [3]. Though Fe comprise about $5 \%$ of the earth's crust and the fourth most abundant element in the lithosphere, Fe deficiency is one of the major yield-limiting factors for crop production in many agricultural regions all over the world, particularly in calcareous soils [3] [4]. Theoretically, total soil-Fe content would be sufficient to meet Fe needs of plants; however, most of the $\mathrm{Fe}$ in the soil is present as inorganic forms, poorly available for root, thus exposing the plant to severe deficiency of this nutrient, which results in the characteristic chlorosis symptoms [3] [4] [5]. Obviously, another mechanism that increases Fe availability to plants exists; otherwise, crops grown on almost all soils would be Fe deficient. In addition to $\mathrm{pH}$ and soil water or aeration as measured by redox, soil organic matter and interactions with other ions in soil solution also affect the availability of Fe [4].

Since $\mathrm{Fe}$ is a vital element for plants, plants evolved different adaptive mechanisms to increase the availability of Fe from soil in response to Fe deficiency stress [2] [3]. Roots of Fe-efficient plants alter their environment to improve the availability and uptake of Fe by some biochemical reactions, such as lowering the $\mathrm{pH}$ in the rhizosphere by roots excretion of $\mathrm{H}^{+}$ions [6], roots excretion of various reducing or chelating compounds [7], rate of reduction $\mathrm{Fe}^{3+}$ to $\mathrm{Fe}^{2+}$ increase at the root [1], organic acids increase in the root sap particularly citrate, adequate transport of Fe from roots to tops, and less accumulation of $\mathrm{P}$ in roots and shoots, even in the presence of relatively high $\mathrm{P}$ in the growth medium [2] [3].

There are two distinct strategies that have evolved specifically in response to the need for absorption of iron [2] [8] [9]. Strategy I, classically considered as a reduction-uptake strategy, one that is characteristic of non-grass monocots and dicots such as pea, tomato, and soybean, protons are extruded, acidifying the rhizosphere. Ferric iron $\left(\mathrm{Fe}^{3+}\right)$ is reduced to ferrous iron $\left(\mathrm{Fe}^{2+}\right)$ at the plasma membrane of root cells by inducible $\mathrm{Fe}^{3+}$ reductase. The reduced iron $\left(\mathrm{Fe}^{2+}\right)$ is then transported across the plasma membrane by a $\mathrm{Fe}^{2+}$ specific transport system [1]. Strategy II, a chelation uptake strategy, conducted by grasses such as maize, barley, and oat, involves the roots extrusion of plant iron carriers (i.e. Phytosiderophores). These compounds form a complex with ferric iron $\left(\mathrm{Fe}^{3+}\right)$ and then $\mathrm{Fe}^{3+}$-siderophore complex transported across the root cell plasma membranes [1]. Both of these modes of iron uptake are greatly enhanced under conditions of iron deficiency [2].

Bio-fortification of crops with micronutrients and health promoting factors during their growing season contributes to improving nutritional quality of 
staple food crops for human consumption and may help reducing the prevalent disease of Fe deficiency anemia world-wide [10] [11]. Recently, agronomic biofortification of crops with micronutrient fertilizers is being as an effective approach to fight hidden hunger or micronutrient deficiency retards the growth and development of both crops and humans [12]. Ramzani et al., [13] reported that integrated use of chemical fertilizers (soil and foliar applied) and organic amendments are effective strategy to increase plant growth and Fe biofortification in cereals while restoring soil health at the same time. In addition, organic materials added to soil produce organic acids, which can serve as chelating agents and stimulate long-distance transport of available $\mathrm{Fe}$ to plants with mediating iron-biofortified crops.

Despite the long history of the discovery of micronutrients in the living organisms, the conditions under which they are taken up, and transported by and within the plant have not been clarified thoroughly and require future study. The aims of the work reported here were 1) to investigate the interaction effect between one macronutrient element (i.e. potassium) and another micronutrient element (i.e. iron) through the absorption and transport; 2) to investigate the effect of different organic chelating agents (e.g. organic acids) on iron uptake by two different plants, monocotyledon, (e.g. maize) and dicotyledon, (e.g. pea).

\section{Materials and Methods}

\subsection{Plant Materials and Growth Conditions}

Two successive experimental studies were carried out to investigate the effect of potassium and exogenous organic acids on iron uptake by two different plants; one is monocotyledon; maize (Zea mays L.) and the second is dicotolydon pea (Pisum sativum L.) grown under controlled conditions.

Sand-culture technique with fine quartz sand size $(0.5 \mathrm{~mm})$ was used as an inert medium after exposure to $1.0 \mathrm{~N} \mathrm{NaOH}$ and $1.0 \mathrm{~N} \mathrm{HCl}$ solution in washing cycles for $24 \mathrm{~h}$, then washing with tap water more than ten times, and finally rinsing with glass-redistilled water three times. The quartz sand was then dried at $105^{\circ} \mathrm{C}$ for $24 \mathrm{~h}$ in oven according to Hewitt, [14].

The seeds of maize (Zea mays L.) and pea (Pisum sativum L.) were washed and soaked for 10 minutes in $1 \% \mathrm{H}_{2} \mathrm{O}_{2}$ then washed and soaked in continuously aerated glass-redistilled water for 24 hours. The seeds were germinated in pots containing one $\mathrm{Kg}$ oven-dried pre-washed sand in a naturally illuminated greenhouse. These seeds were watered daily with glass-redistilled water, and after one week germination period the seedlings were thinned to 3 plants/pot.

\subsection{Experimental Design}

\subsubsection{Effect of Potassium on Iron Uptake by Maize and Pea Plants}

The 7-d-old seedlings of maize (Zea mays L.) and pea (Pisum sativum L.) were irrigated every two days with $100 \mathrm{~mL}$ of one-tenth strength modified nutrient solution of Hoagland and Arnon as a base solution [14], containing combination 
of different iron treatments $\left(0,1\right.$, and $5 \mathrm{ppm}$ as $\left.\mathrm{FeSO}_{4} \cdot 7 \mathrm{H}_{2} \mathrm{O}\right)$ and potassium nutrition $\left(0,5,10\right.$, and $50 \mathrm{ppm}$ as $\left.\mathrm{K}_{2} \mathrm{SO}_{4}\right)$. The $\mathrm{pH}$ of the working nutrient solution was adjusted to 7.5 by the addition of $1 \mathrm{M} \mathrm{KOH}$ or $1 \mathrm{M} \mathrm{HC1}$ as required at the time of solution preparation. Based on the results obtained in this preliminary experiment, combination treatment containing ( $5.0 \mathrm{ppm} \mathrm{Fe}$ as $\mathrm{FeSO}_{4} \cdot 7 \mathrm{H}_{2} \mathrm{O}$ and $50 \mathrm{ppm} \mathrm{K}$ as $\mathrm{K}_{2} \mathrm{SO}_{4}$ ) was selected for further experiment, as it was the treatment that obtained a better biomass production and iron uptake under applied condition.

\subsubsection{Effect of Exogenous Organic Acids on Iron Uptake by Maize and Pea Plants}

The design of this second experiment was similar as the one just mentioned except for its treatment. The 7-d-old seedlings of maize (Zea mays L.) and pea (Pisum sativum L.) were irrigated every two days with $100 \mathrm{~mL}$ of one-tenth strength modified nutrient solution of Hoagland and Arnon as a base solution ( $\mathrm{pH} 7.5$ ), containing $5.0 \mathrm{ppm} \mathrm{Fe}$ as $\mathrm{FeSO}_{4} \cdot 7 \mathrm{H}_{2} \mathrm{O}$ and $50 \mathrm{ppm} \mathrm{K}$ as $\mathrm{K}_{2} \mathrm{SO}_{4}$ and containing $1 \times$ $10^{-5}$ mole/liter one of the following organic acids: Citric acid, Oxalic acid, Formic acid, Acetic acid, Propionic acid, Tartaric acid, Succinic acid, Fumaric acid, Malic acid, Glutamic acid, besides the free organic acid nutrient solution as a control.

Two greenhouse experiments were carried out in a Randomized Complete Block Design (RCBD) and each treatment was repeated five times.

\subsection{Measurements}

After 30 days of growth for each experiment, plants were collected washed carefully to remove all the sand particles adhered to the roots using solution of $10^{-4}$ $\mathrm{M} \mathrm{CaSO}_{4}$, then with glass-redistilled water. The washing period was about half minute.

The plants were placed between dry filter sheet papers to deplete water, and then separated into, roots, nodes, internodes and leaves for maize, or roots, stems and leaves for pea seedlings. Handling and separation of the plants were carried out carefully by finger tips. The plant organs were oven-dried at $65^{\circ} \mathrm{C}$ for 48 hours, and the dry weight was measured, ground in a stainless steel mill and stored for analysis [15]. The root to shoot ratio (R/S) was based on ratio of root dry weight to shoot dry weight.

For mineral nutrient analysis, Fe concentration was measured after wet ashing of oven-dried plant material using atomic absorption spectrophotometer (Varian, spectra AA220) according to Jones Jr, [16]. While, total phosphorus (P) content in plant tissue was determined using the vanadate-molybdate method according to Page et al. [17]. Also, total potassium was determined by flame photometer according to Chapman and pratt [15].

\subsection{Statistical Analyses}

The data obtained were subjected to analysis of variance (ANOVA) according to Gomez and Gomez [18], using CoStat Software Program Version 6.303 [19], and LSD at 0.05 level of significance was used for the comparison between means. 


\section{Results and Discussion}

\subsection{Effect of Potassium on Iron Uptake by Maize and Pea Plants}

Data in Table 1 show the interaction effect between potassium and iron treatments on the dry weight, g.plant ${ }^{-1}$, of maize and pea plants. It is obvious that the dry weight of maize and pea plants were significantly increased with increasing iron and potassium in the nutrient media. In this respect, the interaction between $5.0 \mathrm{ppm} \mathrm{Fe}$ and $50 \mathrm{ppm} \mathrm{K}$ was the best interaction treatment for increasing biomass production of maize and pea seedlings under applied condition.

Among the plant nutrients, $\mathrm{K}$ is a very important nutrient for increasing plant growth, crop yield and obtaining optimal production levels. Proper K nutrition is critical for generating a yield, high quality response, and good storage ability of crop plants [20]. Scientists reported that increasing $\mathrm{K}$ and Fe levels had positive effects on the dry weight of the maize leaves and roots. Both $\mathrm{K}$ and Fe deficiencies cause poor development and chlorosis symptoms in the maize plant. Adequate supply of $\mathrm{K}$ may be required for the efficient use of both Fe and other macronutrient elements. However, too high a concentration of $\mathrm{K}$ will cause competition with iron and other cations [21].

It is clear that the more massive root system (better root to shoot ratio) is almost always a guarantee of more stable performance at every species, crops, and their cultivars [22]. Potassium $\left(\mathrm{K}^{+}\right)$is an essential macronutrient that fulfills critical functions related to root growth, and development of root system architecture [23] [24]. Further, there are also studies showing that root growth retardation is a common response to $\mathrm{K}^{+}$limiting and one possible explanation is the fact that

Table 1. The dry weight, (g.plant ${ }^{-1}$ ), of maize and pea as influenced by different iron and potassium concentrations in the nutrient solution.

\begin{tabular}{|c|c|c|c|c|c|c|c|c|c|c|}
\hline \multirow{2}{*}{\multicolumn{2}{|c|}{ ppm in solution }} & \multicolumn{5}{|c|}{ Monocot Plants (Maize) } & \multicolumn{4}{|c|}{ Dicot Plants (Pea) } \\
\hline & & \multicolumn{3}{|c|}{ Shoots } & \multirow{2}{*}{ Roots } & \multirow{2}{*}{$\begin{array}{l}\text { Root-shoot } \\
\text { ratio }\end{array}$} & \multicolumn{2}{|c|}{ Shoots } & \multirow{2}{*}{ Roots } & \multirow{2}{*}{$\begin{array}{l}\text { Root-shoot } \\
\text { ratio }\end{array}$} \\
\hline $\mathrm{Fe}$ & $\mathrm{K}$ & Nodes & Internodes & Leaves & & & Stems & Leaves & & \\
\hline \multirow[t]{4}{*}{0} & 0 & $0.05^{\mathrm{i}}$ & $0.09^{k}$ & $1.21^{\mathrm{k}}$ & $0.45^{1}$ & $0.33^{\mathrm{g}}$ & $0.20^{\mathrm{i}}$ & $0.43^{\mathrm{k}}$ & $0.23^{\mathrm{k}}$ & $0.37^{\mathrm{h}}$ \\
\hline & 5 & $0.09^{\mathrm{g}}$ & $0.12^{\mathrm{i}}$ & $1.35^{\mathrm{i}}$ & $0.58^{\mathrm{i}}$ & $0.37^{\mathrm{e}}$ & $0.22^{\mathrm{h}}$ & $0.49^{j}$ & $0.27^{\mathrm{j}}$ & $0.39^{g}$ \\
\hline & 10 & $0.13^{\mathrm{f}}$ & $0.17^{\mathrm{h}}$ & $1.39^{9}$ & $0.69^{\mathrm{g}}$ & $0.41^{\mathrm{d}}$ & $0.23^{\mathrm{g}}$ & $0.54^{\mathrm{h}}$ & $0.31^{\mathrm{h}}$ & $0.40^{\mathrm{e}}$ \\
\hline & 50 & $0.18^{\mathrm{e}}$ & $0.21^{\mathrm{f}}$ & $1.46^{\mathrm{c}}$ & $0.81^{\mathrm{d}}$ & $0.44^{\mathrm{b}}$ & $0.25^{\mathrm{e}}$ & $0.62^{\mathrm{e}}$ & $0.37^{\mathrm{d}}$ & $0.43^{\mathrm{b}}$ \\
\hline \multirow[t]{4}{*}{1} & 0 & $0.07^{\mathrm{h}}$ & $0.10^{j}$ & $1.30^{j}$ & $0.50^{\mathrm{k}}$ & $0.34^{\mathrm{f}}$ & $0.24^{\mathrm{f}}$ & $0.52^{\mathrm{i}}$ & $0.28^{\mathrm{i}}$ & $0.37^{\mathrm{h}}$ \\
\hline & 5 & $0.17^{\mathrm{e}}$ & $0.19^{g}$ & $1.34^{\mathrm{i}}$ & $0.65^{\mathrm{h}}$ & $0.38^{\mathrm{e}}$ & $0.26^{\mathrm{e}}$ & $0.58^{\mathrm{g}}$ & $0.32^{\mathrm{g}}$ & $0.39^{\mathrm{fg}}$ \\
\hline & 10 & $0.20^{\mathrm{d}}$ & $0.24^{\mathrm{e}}$ & $1.40^{\mathrm{f}}$ & $0.75^{\mathrm{e}}$ & $0.41^{\mathrm{d}}$ & $0.26^{\mathrm{e}}$ & $0.62^{\mathrm{e}}$ & $0.36^{\mathrm{e}}$ & $0.41^{\mathrm{d}}$ \\
\hline & 50 & $0.25^{\mathrm{b}}$ & $0.30^{c}$ & $1.45^{\mathrm{d}}$ & $0.88^{\mathrm{b}}$ & $0.44^{\mathrm{ab}}$ & $0.27^{\mathrm{d}}$ & $0.69^{c}$ & $0.42^{\mathrm{c}}$ & $0.44^{\mathrm{a}}$ \\
\hline \multirow[t]{4}{*}{5} & 0 & $0.10^{\mathrm{g}}$ & $0.13^{\mathrm{i}}$ & $1.37^{\mathrm{h}}$ & $0.53^{j}$ & $0.33^{\mathrm{fg}}$ & $0.28^{\mathrm{c}}$ & $0.61^{f}$ & $0.33^{\mathrm{f}}$ & $0.37^{\mathrm{h}}$ \\
\hline & 5 & $0.22^{c}$ & $0.27^{\mathrm{d}}$ & $1.41^{\mathrm{e}}$ & $0.70^{f}$ & $0.37^{\mathrm{e}}$ & $0.29^{\mathrm{b}}$ & $0.66^{\mathrm{d}}$ & $0.37^{\mathrm{d}}$ & $0.39^{f}$ \\
\hline & 10 & $0.24^{\mathrm{b}}$ & $0.32^{\mathrm{b}}$ & $1.47^{\mathrm{b}}$ & $0.85^{c}$ & $0.42^{\mathrm{c}}$ & $0.30^{\mathrm{b}}$ & $0.73^{\mathrm{b}}$ & $0.43^{\mathrm{b}}$ & $0.42^{\mathrm{c}}$ \\
\hline & 50 & $0.28^{\mathrm{a}}$ & $0.39^{\mathrm{a}}$ & $1.54^{\mathrm{a}}$ & $0.99^{\mathrm{a}}$ & $0.45^{\mathrm{a}}$ & $0.31^{\mathrm{a}}$ & $0.78^{\mathrm{a}}$ & $0.47^{\mathrm{a}}$ & $0.43^{\mathrm{ab}}$ \\
\hline
\end{tabular}

Means in each column, followed by the same alphabetical letter(s) in common, are not significantly different at $p \leq 0.05$. 
carbohydrates are retained in the shoots of $\mathrm{K}^{+}$deprived plants [24]. Shortage of Fe, on the other hand, had almost no effect on the root to shoot ratio (R/S) [25].

Data in Table 2 and Table 3 show the interaction effect between potassium and iron treatments on the amount of iron ( $\mathrm{ppm})$, and potassium (\%), on dry weight (D.W.) basis of maize and pea plants. The obtained results showed that the maximum Fe-uptake is found when the media contained $5.0 \mathrm{ppm}$ Fe and 50 ppm K. The uptake of potassium increased with both the increase of iron and potassium in the nutrient media.

There is a common effect between iron and potassium on plant growth. The interactions between their roles in the chlorophyll formation, the metabolism reactions and the translocation of different compounds between plant organs are evident but difficult to separate specifically. Scientists reported that deficiency of $\mathrm{K}$ and $\mathrm{Fe}$ caused poor development and chlorosis symptoms in the maize plant, while adequate $\mathrm{K}$ supply is also required for the efficient use of Fe and stimulated growth and enhanced dry matter yield [26].

The interaction among the plant nutrients can be synergistic, antagonistic, zero-interactive and/or Liebig-synergistic [27] [28]. These interactions clarify that the supply of nutrient can affect the function of another nutrient that ultimately influence the crop growth and yield [29]. Potassium (K) has direct synergistic relationships with two micronutrients namely: iron and manganese [28]. Therefore, Fe-biofortification by synergistic action of potassium can be an effective approach to fight hidden hunger retards the growth of monocot and dicot plants.

Table 2. The amount of iron (ppm), on dry weight (D.W.) basis, of maize and pea plants as influenced by the concentrations of iron and potassium in the nutrient solution.

\begin{tabular}{|c|c|c|c|c|c|c|c|c|}
\hline \multirow{2}{*}{\multicolumn{2}{|c|}{ ppm in solution }} & \multicolumn{4}{|c|}{ Monocot Plants (Maize) } & \multicolumn{3}{|c|}{ Dicot Plants (Pea) } \\
\hline & & \multicolumn{4}{|c|}{$\mathrm{Fe}$ (ppm), of D.W. } & \multicolumn{3}{|c|}{$\mathrm{Fe}$ (ppm), of D.W. } \\
\hline \multirow{2}{*}{$\mathrm{Fe}$} & \multirow{2}{*}{$\mathrm{K}$} & \multicolumn{3}{|c|}{ Shoots } & \multirow{2}{*}{ Roots } & \multicolumn{2}{|c|}{ Shoots } & \multirow{2}{*}{ Root } \\
\hline & & Nodes & Internodes & Leaves & & Stems & Leaves & \\
\hline \multirow[t]{4}{*}{0} & 0 & $24^{\mathrm{j}}$ & $26^{\mathrm{k}}$ & $23^{\mathrm{k}}$ & $55^{\mathrm{k}}$ & $42^{j}$ & $41^{\mathrm{ij}}$ & $55^{\mathrm{i}}$ \\
\hline & 5 & $27^{\mathrm{i}}$ & $28^{\mathrm{j}}$ & $25^{\mathrm{jk}}$ & $55^{\mathrm{jk}}$ & $41^{j}$ & $40^{\mathrm{j}}$ & $56^{\mathrm{i}}$ \\
\hline & 10 & $26^{\mathrm{i}}$ & $27^{\mathrm{ij}}$ & $24^{\mathrm{ij}}$ & $56^{\mathrm{j}}$ & $42^{\mathrm{ij}}$ & $41^{\mathrm{ij}}$ & $55^{\mathrm{i}}$ \\
\hline & 50 & $27^{\mathrm{i}}$ & $29^{\mathrm{i}}$ & $26^{\mathrm{i}}$ & $58^{\mathrm{i}}$ & $43^{\mathrm{i}}$ & $42^{\mathrm{i}}$ & $56^{\mathrm{i}}$ \\
\hline \multirow[t]{4}{*}{1} & 0 & $53^{\mathrm{h}}$ & $55^{\mathrm{h}}$ & $51^{\mathrm{h}}$ & $101^{\mathrm{h}}$ & $77^{\mathrm{h}}$ & $75^{\mathrm{h}}$ & $97^{\mathrm{h}}$ \\
\hline & 5 & $58^{g}$ & $59^{g}$ & $56^{g}$ & $108^{g}$ & $80^{g}$ & $78^{g}$ & $100^{g}$ \\
\hline & 10 & $62^{\mathrm{f}}$ & $64^{\mathrm{f}}$ & $60^{\mathrm{f}}$ & $112^{\mathrm{f}}$ & $84^{\mathrm{f}}$ & $80^{\mathrm{f}}$ & $101^{\mathrm{f}}$ \\
\hline & 50 & $66^{\mathrm{e}}$ & $68^{e}$ & $65^{e}$ & $119^{\mathrm{e}}$ & $86^{\mathrm{e}}$ & $82^{\mathrm{e}}$ & $103^{\mathrm{e}}$ \\
\hline \multirow[t]{4}{*}{5} & 0 & $73^{\mathrm{d}}$ & $75^{\mathrm{d}}$ & $70^{\mathrm{d}}$ & $126^{\mathrm{d}}$ & $87^{\mathrm{d}}$ & $85^{\mathrm{d}}$ & $105^{\mathrm{d}}$ \\
\hline & 5 & $78^{c}$ & $81^{\mathrm{c}}$ & $76^{c}$ & $130^{c}$ & $90^{c}$ & $88^{c}$ & $108^{c}$ \\
\hline & 10 & $84^{\mathrm{b}}$ & $86^{\mathrm{b}}$ & $83^{\mathrm{b}}$ & $140^{\mathrm{b}}$ & $94^{\mathrm{b}}$ & $90^{\mathrm{b}}$ & $110^{\mathrm{b}}$ \\
\hline & 50 & $88^{\mathrm{a}}$ & $90^{\mathrm{a}}$ & $87^{\mathrm{a}}$ & $145^{\mathrm{a}}$ & $96^{\mathrm{a}}$ & $93^{\mathrm{a}}$ & $112^{\mathrm{a}}$ \\
\hline
\end{tabular}

Means in each column, followed by the same alphabetical letter(s) in common, are not significantly different at $p \leq 0.05$. 
Table 3. The amount of potassium (\%), on dry weight (D.W.) basis, of maize and pea plants as influenced by the concentrations of iron and potassium in the nutrient solution.

\begin{tabular}{|c|c|c|c|c|c|c|c|c|}
\hline \multirow{2}{*}{\multicolumn{2}{|c|}{ ppm in solution }} & \multicolumn{4}{|c|}{ Monocot Plants (Maize) } & \multicolumn{3}{|c|}{ Dicot Plants (Pea) } \\
\hline & & \multicolumn{4}{|c|}{ K (\%), of D.W. } & \multicolumn{3}{|c|}{ K (\%), of D.W. } \\
\hline \multirow{2}{*}{$\mathrm{Fe}$} & \multirow{2}{*}{$\mathrm{K}$} & \multicolumn{3}{|c|}{ Shoots } & \multirow{2}{*}{ Roots } & \multicolumn{2}{|c|}{ Shoots } & \multirow{2}{*}{ Roots } \\
\hline & & Nodes & Internodes & Leaves & & Stems & Leaves & \\
\hline \multirow[t]{4}{*}{0} & 0 & $1.39^{\mathrm{i}}$ & $1.24^{\mathrm{k}}$ & $1.65^{\mathrm{g}}$ & $0.86^{\mathrm{g}}$ & $1.18^{\mathrm{i}}$ & $1.00^{\mathrm{k}}$ & $1.28^{\mathrm{h}}$ \\
\hline & 5 & $1.81^{\mathrm{g}}$ & $1.55^{\mathrm{i}}$ & $2.11^{\mathrm{e}}$ & $1.06^{\mathrm{e}}$ & $1.70^{\mathrm{g}}$ & $1.53^{\mathrm{i}}$ & $1.80^{\mathrm{f}}$ \\
\hline & 10 & $1.90^{\mathrm{f}}$ & $1.62^{\mathrm{g}}$ & $2.21^{\mathrm{d}}$ & $1.09^{\mathrm{d}}$ & $1.79^{\mathrm{f}}$ & $1.61^{\mathrm{h}}$ & $1.90^{\mathrm{e}}$ \\
\hline & 50 & $2.00^{\mathrm{d}}$ & $1.78^{\mathrm{d}}$ & $2.30^{c}$ & $1.12^{\mathrm{c}}$ & $1.87^{\mathrm{e}}$ & $1.75^{\mathrm{d}}$ & $2.05^{\mathrm{c}}$ \\
\hline \multirow[t]{4}{*}{1} & 0 & $1.40^{\mathrm{hi}}$ & $1.25^{\mathrm{j}}$ & $1.72^{\mathrm{f}}$ & $0.91^{\mathrm{f}}$ & $1.19^{\mathrm{hi}}$ & $1.03^{j}$ & $1.31^{\mathrm{g}}$ \\
\hline & 5 & $1.88^{\mathrm{f}}$ & $1.60^{\mathrm{h}}$ & $2.20^{\mathrm{d}}$ & $1.07^{\mathrm{e}}$ & $1.80^{\mathrm{f}}$ & $1.63^{\mathrm{g}}$ & $1.88^{\mathrm{e}}$ \\
\hline & 10 & $1.95^{\mathrm{e}}$ & $1.66^{\mathrm{f}}$ & $2.30^{c}$ & $1.11^{\mathrm{c}}$ & $1.89^{\mathrm{d}}$ & $1.70^{\mathrm{f}}$ & $1.95^{\mathrm{d}}$ \\
\hline & 50 & $2.10^{\mathrm{c}}$ & $1.80^{\mathrm{c}}$ & $2.41^{\mathrm{b}}$ & $1.14^{\mathrm{b}}$ & $1.93^{\mathrm{c}}$ & $1.80^{\mathrm{c}}$ & $2.08^{\mathrm{b}}$ \\
\hline \multirow[t]{4}{*}{5} & 0 & $1.42^{\mathrm{h}}$ & $1.26^{j}$ & $1.74^{\mathrm{f}}$ & $0.92^{\mathrm{f}}$ & $1.20^{\mathrm{h}}$ & $1.01^{\mathrm{k}}$ & $1.30^{\mathrm{gh}}$ \\
\hline & 5 & $1.93^{\mathrm{e}}$ & $1.70^{\mathrm{e}}$ & $2.33^{\mathrm{c}}$ & $1.12^{\mathrm{c}}$ & $1.88^{\mathrm{de}}$ & $1.71^{\mathrm{e}}$ & $1.96^{\mathrm{d}}$ \\
\hline & 10 & $2.15^{\mathrm{b}}$ & $1.90^{\mathrm{b}}$ & $2.40^{\mathrm{b}}$ & $1.15^{\mathrm{b}}$ & $1.96^{\mathrm{b}}$ & $1.82^{\mathrm{b}}$ & $2.08^{\mathrm{b}}$ \\
\hline & 50 & $2.26^{\mathrm{a}}$ & $2.00^{\mathrm{a}}$ & $2.55^{\mathrm{a}}$ & $1.20^{\mathrm{a}}$ & $2.02^{\mathrm{a}}$ & $1.90^{\mathrm{a}}$ & $2.13^{\mathrm{a}}$ \\
\hline
\end{tabular}

Means in each column, followed by the same alphabetical letter(s) in common, are not significantly different at $p \leq 0.05$.

Several studies have demonstrated that adequate supplied of $\mathrm{K}$ can alleviate $\mathrm{Fe}$ deficiency-induced chlorosis in plants [21] [26] [30]. Ye et al. [30] investigated the major mechanism underlying K-mediated amelioration of Fe-deficiency in Arabidopsis plants. Results revealed that under Fe-deficient condition, K supply significantly increased the secretion of phenolic compounds and the degree of pectin methylation, while decreased pectin and hemicellulose contents, thereby promoting Fe reutilization from root cell walls. Furthermore, K supply also enhanced the reutilization of $\mathrm{Fe}$ from vacuoles through up-regulation of $A t$ $N R A M P 3$ expression. In addition, $\mathrm{K}$ supply stimulated several genes associated with long-distance transport of Fe expression, including AtFRD3, AtYSL2, and AtNAS1, suggesting adequate supply of $\mathrm{K}$ can improve $\mathrm{Fe}$ transportation from roots to leaves.

Table 4 shows the interaction effect between potassium and iron treatments on the amount of phosphorus (\%), on dry weight (D.W.) basis of maize and pea plants. The obtained results showed that the phosphorus uptake reached its maximum at the level of $5.0 \mathrm{ppm} \mathrm{Fe}$ and $50 \mathrm{ppm} \mathrm{K}$ in the nutrient media.

The antagonistic interaction between iron $(\mathrm{Fe})$ and phosphorus $(\mathrm{P})$ has been noted in the area of plant nutrition [31]. However, under adequate Fe supply, $\mathrm{P}$ concentrations remained above critical deficiency levels in maize and pea plants. Several studies were made of the interactions between iron and phosphorus in their effects upon the dry matter production, iron and phosphorus uptake with 
maize in solution culture. The results revealed that iron above $5 \mathrm{mg}$ per liter adversely affected the growth as well as $\mathrm{P}$ uptake [32]. Therefore, achieving balanced plant nutrition is one of the main factors affecting growth, yield and quality of maize and pea plants.

Table 4. The amount of phosphorus (\%), on dry weight (D.W.) basis, of maize and pea plants as influenced by the concentrations of iron and potassium in the nutrient solution.

\begin{tabular}{|c|c|c|c|c|c|c|c|c|}
\hline \multirow{2}{*}{\multicolumn{2}{|c|}{ ppm in solution }} & \multicolumn{4}{|c|}{ Monocot Plants (Maize) } & \multicolumn{3}{|c|}{ Dicot Plants (Pea) } \\
\hline & & \multicolumn{4}{|c|}{ P (\%), of D.W. } & \multicolumn{3}{|c|}{ P (\%), of D.W. } \\
\hline \multirow{2}{*}{$\mathrm{Fe}$} & \multirow{2}{*}{$\mathrm{K}$} & \multicolumn{3}{|c|}{ Shoots } & \multirow{2}{*}{ Roots } & \multicolumn{2}{|c|}{ Shoots } & \multirow{2}{*}{ Roots } \\
\hline & & Nodes & Internodes & Leaves & & Stems & Leaves & \\
\hline \multirow[t]{4}{*}{0} & 0 & $0.30^{\mathrm{e}}$ & $0.32^{\mathrm{f}}$ & $0.36^{\mathrm{ef}}$ & $0.30^{c}$ & $0.32^{\mathrm{g}}$ & $0.31^{\mathrm{h}}$ & $0.36^{\mathrm{g}}$ \\
\hline & 5 & $0.31^{\mathrm{d}}$ & $0.33^{\mathrm{e}}$ & $0.35^{\mathrm{f}}$ & $0.29^{\mathrm{e}}$ & $0.35^{\mathrm{e}}$ & $0.33^{\mathrm{g}}$ & $0.37^{\mathrm{f}}$ \\
\hline & 10 & $0.32^{c}$ & $0.35^{\mathrm{d}}$ & $0.36^{\mathrm{de}}$ & $0.29^{\mathrm{de}}$ & $0.38^{\mathrm{c}}$ & $0.36^{\mathrm{d}}$ & $0.40^{\mathrm{d}}$ \\
\hline & 50 & $0.34^{\mathrm{b}}$ & $0.37^{\mathrm{b}}$ & $0.39^{\mathrm{b}}$ & $0.32^{\mathrm{ab}}$ & $0.41^{\mathrm{a}}$ & $0.40^{\mathrm{a}}$ & $0.44^{\mathrm{a}}$ \\
\hline \multirow[t]{4}{*}{1} & 0 & $0.31^{\mathrm{d}}$ & $0.32^{\mathrm{f}}$ & $0.37^{\mathrm{d}}$ & $0.31^{\mathrm{c}}$ & $0.33^{\mathrm{f}}$ & $0.31^{\mathrm{h}}$ & $0.36^{\mathrm{g}}$ \\
\hline & 5 & $0.32^{\mathrm{c}}$ & $0.34^{\mathrm{e}}$ & $0.36^{\mathrm{de}}$ & $0.29^{\mathrm{d}}$ & $0.36^{\mathrm{d}}$ & $0.34^{\mathrm{f}}$ & $0.38^{\mathrm{e}}$ \\
\hline & 10 & $0.33^{\mathrm{c}}$ & $0.36^{\mathrm{c}}$ & $0.37^{\mathrm{d}}$ & $0.30^{c}$ & $0.39^{\mathrm{b}}$ & $0.37^{\mathrm{d}}$ & $0.41^{\mathrm{c}}$ \\
\hline & 50 & $0.35^{\mathrm{b}}$ & $0.38^{\mathrm{a}}$ & $0.39^{\mathrm{b}}$ & $0.32^{\mathrm{ab}}$ & $0.41^{\mathrm{a}}$ & $0.39^{\mathrm{b}}$ & $0.43^{\mathrm{a}}$ \\
\hline \multirow[t]{4}{*}{5} & 0 & $0.30^{\mathrm{e}}$ & $0.32^{\mathrm{f}}$ & $0.36^{\mathrm{ef}}$ & $0.31^{\mathrm{bc}}$ & $0.34^{\mathrm{f}}$ & $0.32^{\mathrm{h}}$ & $0.37^{f}$ \\
\hline & 5 & $0.33^{c}$ & $0.35^{\mathrm{cd}}$ & $0.38^{c}$ & $0.30^{c}$ & $0.38^{c}$ & $0.35^{\mathrm{e}}$ & $0.39^{\mathrm{d}}$ \\
\hline & 10 & $0.34^{\mathrm{b}}$ & $0.37^{\mathrm{b}}$ & $0.38^{\mathrm{c}}$ & $0.31^{\mathrm{bc}}$ & $0.40^{\mathrm{b}}$ & $0.38^{\mathrm{c}}$ & $0.42^{\mathrm{b}}$ \\
\hline & 50 & $0.36^{\mathrm{a}}$ & $0.39^{\mathrm{a}}$ & $0.40^{\mathrm{a}}$ & $0.32^{\mathrm{a}}$ & $0.42^{\mathrm{a}}$ & $0.40^{\mathrm{a}}$ & $0.44^{\mathrm{a}}$ \\
\hline
\end{tabular}

Means in each column, followed by the same alphabetical letter(s) in common, are not significantly different at $p \leq 0.05$.

\subsection{Effect of Exogenous Organic Acids on Iron Uptake by Maize and Pea Plants}

Figure 1 shows the dry weight, (g.plant ${ }^{-1}$ ), of maize (Figure $1(\mathrm{~A})$ ) and pea (Figure 1(B)) plants, as influenced by the presence of different organic acids, 5 $\mathrm{ppm} \mathrm{Fe}$ and $50 \mathrm{ppm} \mathrm{K}$ in the nutrient solution. It is obvious from Figure 1 that the dry weight of maize and pea plants were significantly increased when different organic acids were used with the nutrient media.

Organic acids in the soil originate from a variety of sources that may include plant root exudates, microorganisms and organic matter decomposition. Also, organic acids synthesis in the soil environment may reflect a natural response of biological systems as an adaptation mechanism to biotic and abiotic stresses [3] [33]. There are several significant roles of soil organic acids in the rhizosphere, such as modifying the physico-chemical properties of the soil rhizosphere that may help facilitate uptake of deficient, unavailable, and insoluble nutrients. Moreover, due to their chelating characteristics, they are able to form complexes with components of soil minerals leading to the release of unavailable nutrients for plant growth and development with enabling more efficient acquisition of 
required nutrients [4] [33].

Also, foliar application of the organic acids such as (succinic acid, citric acid, malic acid, and oxalic acid) increase plant growth and root activity in plant [34].

Bolan et al. [35] found that the addition of a wide range of low-molecular-weight organic acids such as oxalic and citric acids increased the dry matter yield of ryegrass. The organic acids also acted as a source of $\mathrm{C}$ for microorganisms and thereby influenced the rhizosphere microbial population and subsequent plant growth.
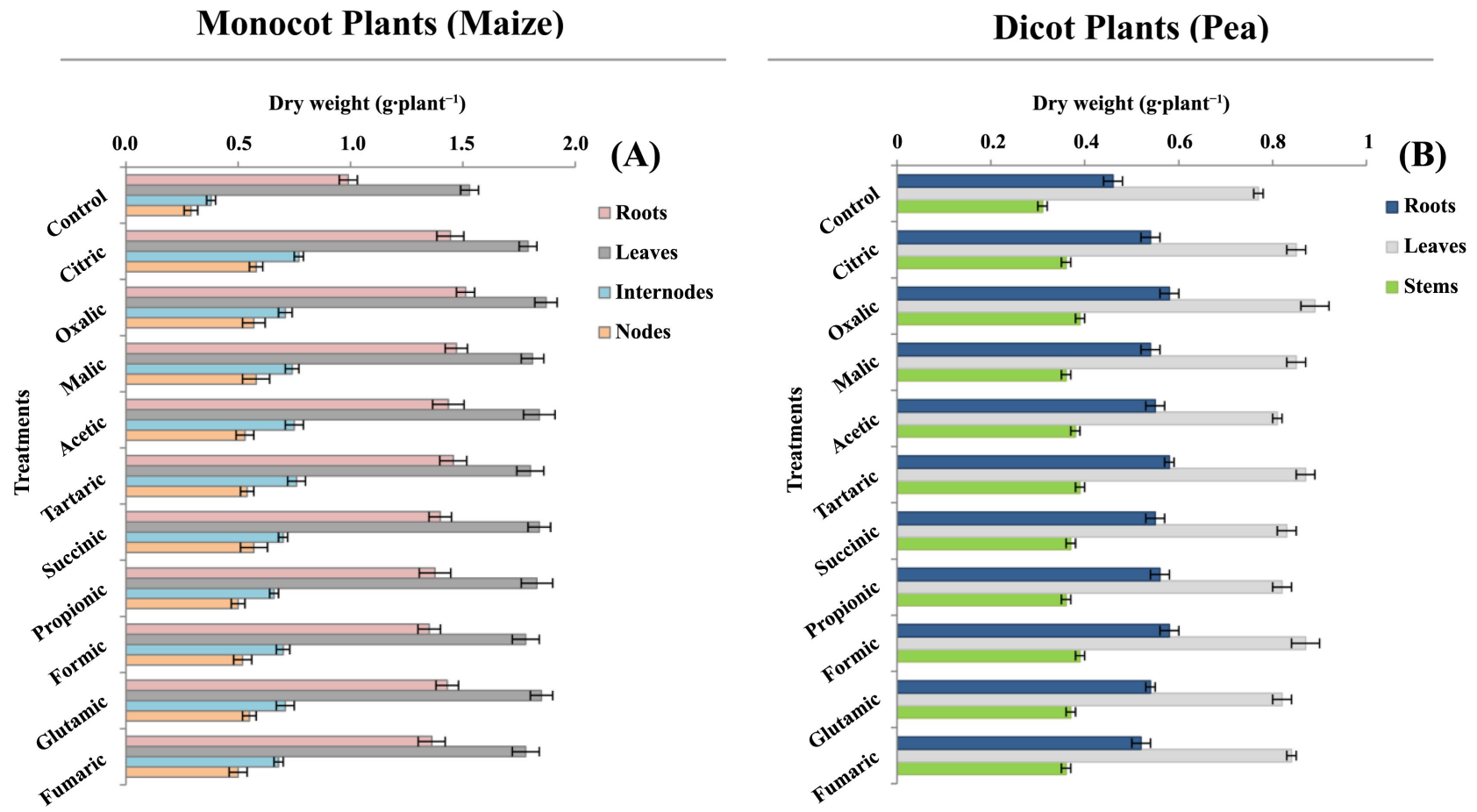

Figure 1. The dry weight, (g.plant ${ }^{-1}$ ), of maize (A) and pea (B), as influenced by the presence of organic acids, 5 ppm Fe and 50 ppm $\mathrm{K}$ in the nutrient solution. Error bars represent standard deviation of the mean.

Figure 2 shows Fe concentration, (ppm), of maize (Figure 2(A)) and pea (Figure 2(B)) plants, as influenced by the presence of organic acids, $5 \mathrm{ppm} \mathrm{Fe}$ and $50 \mathrm{ppm} \mathrm{K}$ in the nutrient solution. The obtained results showed that there is a favorable uptake and translocation of Fe by the maize and pea plants in the presence of the exogenous organic acids in the nutrient media. Organic acids serve as chelators that bond with Fe and other metals, increasing their solubility and their supply to plant roots.

Havlin et al., [3] reported that numerous natural organic compounds in soil, or synthetic compounds added to soils, are able to complex, or chelate $\mathrm{Fe}^{3+}$ and other micronutrients. The Fe concentration in solution and the quantity of $\mathrm{Fe}$ transported to the root by mass flow and diffusion can be greatly increased through complexation of $\mathrm{Fe}$ with natural organic chelating compounds in the soil. Natural organic chelates in soils are products of microbial activity and degradation of soil organic matter $(\mathrm{OM})$ and plant residues, Root exudates are also capable of complexing micronutrients. The dynamics of chelation is an ex- 
tremely important mechanism in soils that greatly contributes to plant available Fe and other micronutrients.

Scientists reported that under optimal growth conditions for a plant utilizing a reductive-bound mechanism of Fe acquisition (dicots and non-grass monocots), it can be expected that citrate and malate may be able to satisfy a significant proportion of the plant's Fe demand through the formation of plant-available organic- $\mathrm{Fe}^{3+}$ complexes in the rhizosphere [36].
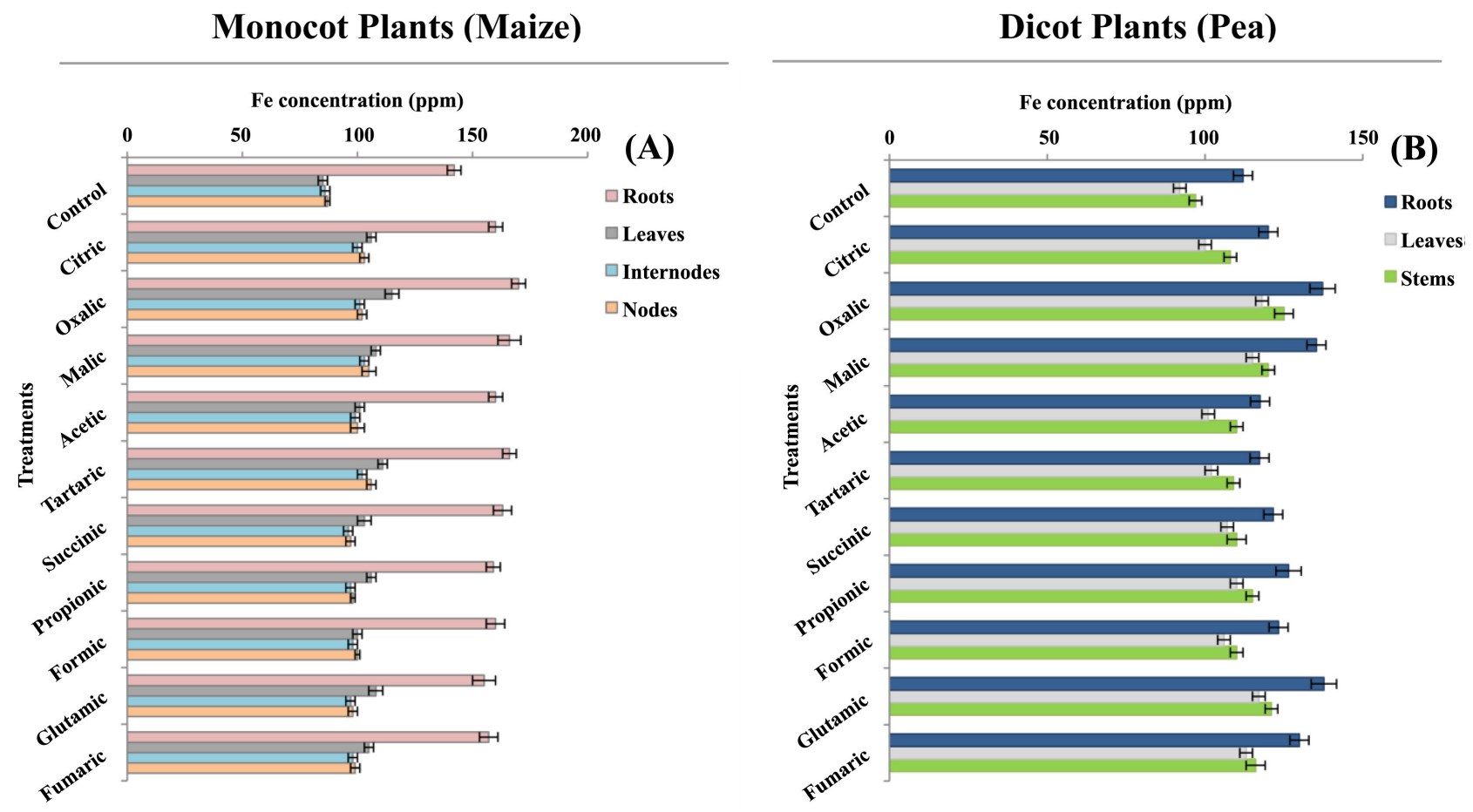

Figure 2. Fe concentration, (ppm), of maize (A) and pea (B), as influenced by the presence of organic acids, 5 ppm Fe and 50 ppm $\mathrm{K}$ in the nutrient solution. Error bars represent standard deviation of the mean.

Plants developed in calcisol soils have limitations in iron nutrition, so exogenous applications of organic acids plus iron chelate can be an alternative. Applications of citric acid (CA), oxalic acid (OA), and humic complexes (HCs) in the nutrient solution in combination with EDTA-type chelate improved the characteristics of the ferric nutrition of tomato plants developed in calcisol soil [37].

Figure 3 shows K concentration, (\%), of maize (Figure 3(A)) and pea (Figure 3(B)) plants, as influenced by the presence of organic acids, 5 ppm Fe and 50 ppm $\mathrm{K}$ in the nutrient solution. It is clear, that there is a favorable uptake and translocation of nutrient such as iron, potassium and phosphorus by the maize and pea plants in the presence of the exogenous organic acids in the nutrient media.

In typical rice soils, experiments were carried out to examine the effect of oxalic acid on release kinetics of potassium $(\mathrm{K})$ from soils along with adsorption and desorption of soil $\mathrm{K}^{+}$. The results revealed that oxalic acid solution with low 
$\mathrm{pH}$ was able to release more $\mathrm{K}$. Oxalic acid decreased soil $\mathrm{K}^{+}$adsorption and increased desorption, the effect of which tended to be greater at lower $\mathrm{pH}$ [38].

In calcareous soils, nonexchangeable $\mathrm{K}^{+}$constitutes a slowly available reserve that may significantly influence $\mathrm{K}^{+}$fertility of soils and plant growth. Jalali and Zarabi, [39] reported that the effect of Oxalic acid (OA) on releasing $\mathrm{K}^{+}$is attributed to the dissociated $\mathrm{H}^{+}$ions and complexing organic ligands in the $\mathrm{OA}$ solutions. Thus, the increase in nonexchangeable $\mathrm{K}^{+}$by $0.01 \mathrm{M}$ oxalic acid can be attributed to the acidic conditions produced by adding oxalic acid which may have dissolved minerals present, exposing interlayer, and mineral $\mathrm{K}^{+}$in calcareous soils.
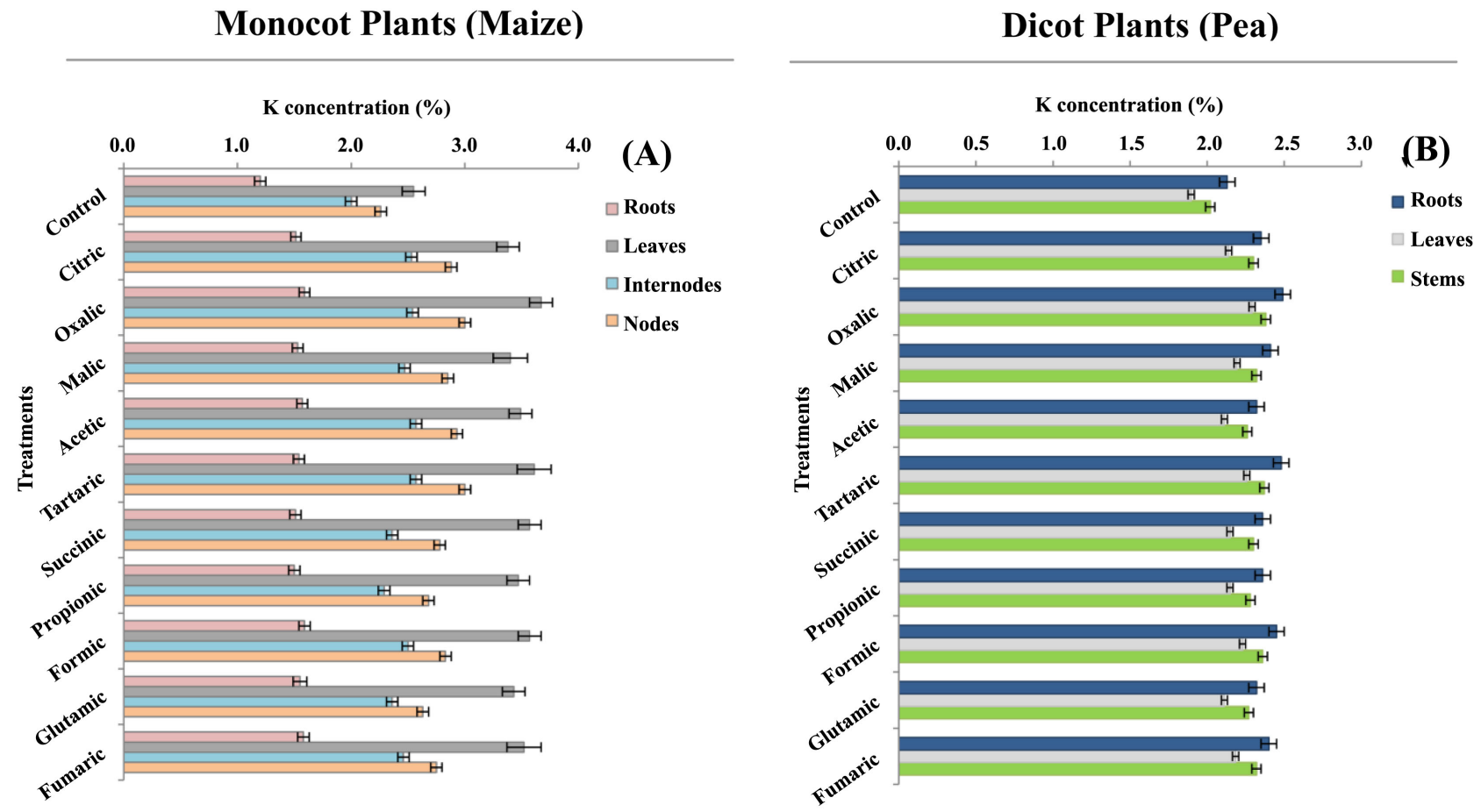

Figure 3. K concentration, (\%), of maize (A) and pea (B), as influenced by the presence of organic acids, $5 \mathrm{ppm}$ Fe and $50 \mathrm{ppm} \mathrm{K}$ in the nutrient solution. Error bars represent standard deviation of the mean.

Figure 4 shows $\mathrm{P}$ concentration, (\%), of maize (Figure 4(A)) and pea (Figure 4(B)) plants, as influenced by the presence of organic acids, $5 \mathrm{ppm}$ Fe and 50 ppm K in the nutrient solution. The obtained results from Figure 4 revealed that exogenous application of organic acids can induce positive changes in the acquisition of $\mathrm{P}$ by maize and pea plants.

One of the strategies of the plants growing in (P)-deficient environments is to exudate low-molecular-weight organic acids (LMWOA). Scientists reported that the maximum $\mathrm{P}$ concentration in barley grain was obtained at $30 \mathrm{mmol} \cdot \mathrm{kg}^{-1}$ LMWOA treatments such as (malic acid, oxalic acid, citric acid, acetic acid, ascorbic acid). As a result, it was found that oxalic acid was the most effective LMWOA in increasing nutrient uptake induced grain yield with and without phosphorous fertilizer application [40]. 
Organic acids play an important role in P availability in soils. Andrade et al. [41] reported that the addition of organic acids influenced dry matter production and $\mathrm{P}$ uptake by corn plants in Oxisols. The effectiveness of organic acids in increasing $\mathrm{P}$ uptake and dry-matter production of corn plants followed the order humic acids, citric acid, and acetic acid, respectively. In Oxisols, the greatest dry-matter production and $\mathrm{P}$ uptake were obtained when organic acids were applied to the soil before $\mathrm{P}$ was added. Organic acids can be adsorbed with great energy by the soil mineral fraction, reducing $\mathrm{P}$ adsorption and increasing $\mathrm{P}$ availability to plants.
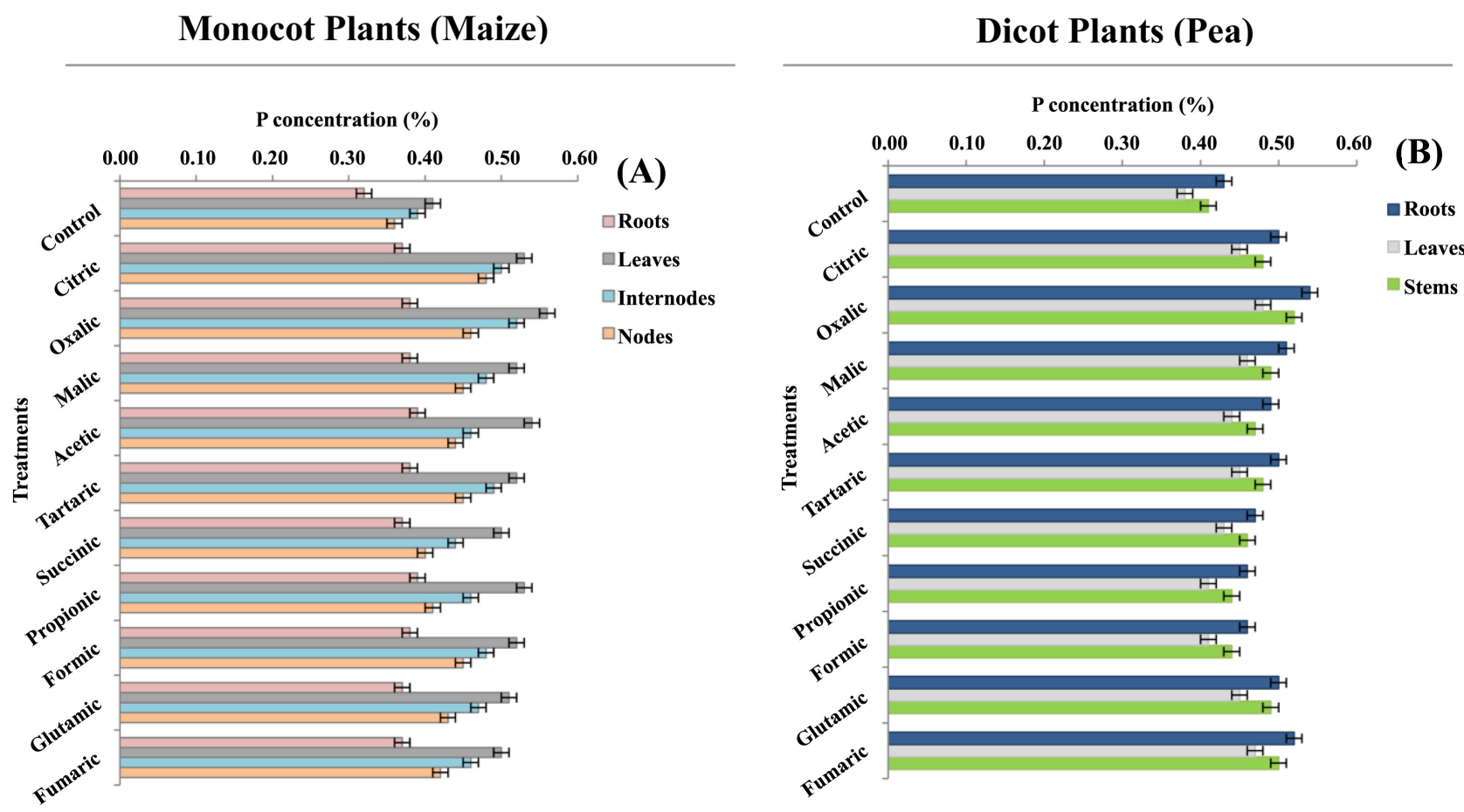

Figure 4. $\mathrm{P}$ concentration, (\%), of maize (A) and pea (B), as influenced by the presence of organic acids, $5 \mathrm{ppm}$ Fe and $50 \mathrm{ppm} \mathrm{K}$ in the nutrient solution. Error bars represent standard deviation of the mean.

\section{Conclusions}

Balanced plant nutrition is one of the main factors affecting growth and quality of monocot and dicot plants. In addition, bio-fortification of crop plants with $\mathrm{Fe}$ is a sustainable agricultural strategy for reducing severe Fe-deficiency malnutrition.

The present study has shown that the interaction between $5.0 \mathrm{ppm}$ Fe and 50 ppm $\mathrm{K}$ was the best interaction treatment for increasing biomass production and iron uptake of maize and pea seedlings under applied condition. Adequate supply of $\mathrm{K}$ is required for better root to shoot ratio (R/S) and efficient use of Fe and other macronutrient elements with stimulating growth of maize and pea plants. Also, under adequate Fe supply, $\mathrm{P}$ concentrations remained above critical deficiency levels in maize and pea plants. Furthermore, exogenous application of organic acids improves uptake and translocation of nutrient such as iron, potassium and phosphorus by the maize and pea plants. Therefore, potassium nutri- 
tion and exogenous organic acids have the potential to stimulate Fe-uptake of monocot and dicot plants and mediate iron-biofortified crops.

In conclusion, Fe-biofortification by synergistic action of potassium and exogenous application of organic acids can be effective approaches to fight hidden hunger retards the growth of monocot and dicot plants.

\section{Conflicts of Interest}

The authors declare no conflicts of interest regarding the publication of this paper.

\section{References}

[1] Krohling, C.A., Eutrópio, F.J., Bertolazi, A.A., Dobbss, L.B., Campostrini, E., Dias, T. and Ramos, A.C. (2016) Ecophysiology of Iron Homeostasis in Plants. Soil Science and Plant Nutrition, 62, 39-47. https://doi.org/10.1080/00380768.2015.1123116

[2] Epstein, E. and Bloom, A.J. (2005) Mineral Nutrition of Plants: Principles and Perspectives. 2nd Edition, Sinauer Associates Inc., Sunderland.

[3] Havlin, J.L., Beaton, J.D., Tisdale, S.L. and Nelson, W.L. (1999) Soil Fertility and Fertilizers: An Introduction to Nutrient Management. 6th Edition, Prentice Hall, Upper Saddle River.

[4] Prasad, R. and Power, J.F. (1997) Soil Fertility Management for Sustainable Agriculture. CRC Press, Boca Raton.

[5] Jelali, N., El Beyrouthy, M., Dell'orto, M., Gharsalli, M. and Mnif, W. (2013) Effects of Fe Deficiency on Organic Acid Metabolism in Pisum sativum Roots. Advances in Crop Science and Technology, 1, 2-4.

[6] Hinsinger, P., Plassard, C., Tang, C. and Jaillard, B. (2003) Origins of Root-Mediated $\mathrm{pH}$ Changes in the Rhizosphere and Their Responses to Environmental Constraints: A Review. Plant and Soil, 248, 43-59. https://doi.org/10.1023/A:1022371130939

[7] Rengel, Z. (2015) Availability of Mn, Zn and Fe in the Rhizosphere. Journal of Soil Science and Plant Nutrition, 15, 397-409. https://doi.org/10.4067/S0718-95162015005000036

[8] Waters, B.M., Amundsen, K. and Graef, G. (2018) Gene Expression Profiling of Iron Deficiency Chlorosis Sensitive and Tolerant Soybean Indicates Key Roles for Phenylpropanoids under Alkalinity Stress. Frontiers in Plant Science, 9, 10. https://doi.org/10.3389/fpls.2018.00010

[9] Murata, Y., Itoh, Y., Iwashita, T. and Namba, K. (2015) Transgenic Petunia with the Iron (III)-Phytosiderophore Transporter Gene Acquires Tolerance to Iron Deficiency in Alkaline Environments. PLOS ONE, 10, e0120227. https://doi.org/10.1371/journal.pone.0120227

[10] Ku, Y., Rehman, H.M. and Lam, H. (2019) Possible Roles of Rhizospheric and Endophytic Microbes to Provide a Safe and Affordable Means of Crop Biofortification. Agronomy, 9, 764. https://doi.org/10.3390/agronomy9110764

[11] Mostafa, D.M., Awd Allah, S.F.A. and Awad-Allah, E.F.A. (2019) Potential of Pleurotus sajor-caju Compost for Controlling Meloidogyne incognita and Improve Nutritional Status of Tomato Plants. Journal of Plant Science and Phytopathology, 3, 118-127. https://doi.org/10.29328/journal.jpsp.1001042

[12] De Valença, A.W., Bake, A., Brouwer, I.D. and Giller, K.E. (2017) Agronomic Biofortification of Crops to Fight Hidden Hunger in Sub-Saharan Africa. Global Food 
Security, 12, 8-14. https://doi.org/10.1016/j.gfs.2016.12.001

[13] Ramzani, P.M.A., Khalid, M., Naveed, M., Ahmad, R. and Shahid, M. (2016) Iron Biofortification of Wheat Grains through Integrated Use of Organic and Chemical Fertilizers in pH Affected Calcareous Soil. Plant Physiology and Biochemistry, 104, 284-293. https://doi.org/10.1016/j.plaphy.2016.04.053

[14] Hewitt, E.J. (1966) Sand and Water Culture Methods Used in the Study of Plant Nutrition. Technical Communication No. 22, Commonwealth Bureau, London.

[15] Chapman, H.D. and Pratt, P.F. (1961) Methods of Analysis for Soils, Plants and Waters. University of California, Division of Agricultural Science, Los Angeles.

[16] Jones, J.B. (2001) Laboratory Guide for Conducting Soil Tests and Plant Analysis. CRC Press, Boca Raton. https://doi.org/10.1201/9781420025293

[17] Page, A.L., Miller, R.H. and Keeney, D.R. (1982) Methods of Soil Analysis. Part 2: Chemical and Microbiological Properties. 2nd Edition, Agron. No. 9 (Part 2) in the Agronomy Series, ASA, SSSA, Inc., Madison.

[18] Gomez, K.A. and Gomez, A.A. (1984) Statistical Procedures for Agricultural Research. 2nd Edition, A Wiley-Interscience Publication, John Wiley and Sons, New York.

[19] CoStat Software (2004) Microcomputer Program Analysis. Version 6.303. CoHort Software, Monterey.

[20] Awad-Allah, E.F.A., Attia, M.G. and Mahdy, A.M. (2020) Salinity Stress Alleviation by Foliar Bio-Stimulant, Proline and Potassium Nutrition Promotes Growth and Yield Quality of Garlic Plant. Open Journal of Soil Science (OJSS), 10, 443-458. https://doi.org/10.4236/ojss.2020.109023

[21] Çelik, H., Aşık, B.B., Gürel, S. and Katkat, A.V. (2010a) Effect of Potassium and Iron on Macro Element Uptake of Maize. Zemdirbyste-Agriculture, 97, 11-22.

[22] Bláha, L. (2019) Importance of Root-Shoot Ratio for Crops Production. Journal of Agronomy \& Agricultural Science, 2, 12. https://doi.org/10.24966/AAS-8292/100012

[23] Xu, X., Du, X., Wang, F., Sha, J., Chen, Q., Tian, G., Zhu, Z., Ge, S. and Jiang, Y. (2020) Effects of Potassium Levels on Plant Growth, Accumulation and Distribution of Carbon, and Nitrate Metabolism in Apple Dwarf Rootstock Seedlings. Frontiers in Plant Science, 11, 904. https://doi.org/10.3389/fpls.2020.00904

[24] Sustr, M., Soukup, A. and Tylova, E. (2019) Potassium in Root Growth and Development. Plants, 8, 435. https://doi.org/10.3390/plants8100435

[25] Ericsson, T. (1995) Growth and Shoot: Root Ratio of Seedlings in Relation to Nutrient Availability. Plant and Soil, 168-169, 205-214.

https://doi.org/10.1007/BF00029330

[26] Çelik, H., Aşı, B.B., Gürel, S. and Katkat, A.V. (2010b) Potassium as an Intensifying Factor for Iron Chlorosis. International Journal of Agriculture and Biology, 3, 359-364.

[27] Rietra, R.P.J.J., Heinen, M., Dimkpa, C.O. and Bindraban, P.S. (2017) Effects of Nutrient Antagonism and Synergism on Yield and Fertilizer Use Efficiency. Communications in Soil Science and Plant Analysis, 48, 1895-1920. https://doi.org/10.1080/00103624.2017.1407429

[28] Ranade-Malvi, U.R. (2011) Interaction of Micronutrients with Major Nutrients with Special Reference to Potassium. Karnataka Journal of Agricultural Sciences, 24, 106-109. 
[29] Ramzan, Y., Hafeez, M.B., Khan, S., et al. (2020) Biofortification with Zinc and Iron Improves the Grain Quality and Yield of Wheat Crop. International Journal of Plant Production, 14, 501-510. https://doi.org/10.1007/s42106-020-00100-w

[30] Ye, Y.Q., Luo, H.Y., Li, M., et al. (2019) Potassium Ameliorates Iron Deficiency by Facilitating the Remobilization of Iron from Root Cell Walls and Promoting Its Translocation from Roots to Shoots. Plant Soil, 440, 507-521. https://doi.org/10.1007/s11104-019-04111-Z

[31] Zheng, L., Huang, F., Narsai, R., Wu, J., Giraud, E., He, F., Cheng, L., Wang, F., Wu, P., Whelan, J. and Shou, H. (2009) Physiological and Transcriptome Analysis of Iron and Phosphorus Interaction in Rice Seedlings. Plant Physiology, 151, 262-274. https://doi.org/10.1104/pp.109.141051

[32] Mathan, K.K. and Amberger, A. (1977) Influence of Iron on the Uptake of Phosphorus by Maize. Plant and Soil, 46, 413-422. https://doi.org/10.1007/BF00010097

[33] Adeleke, R., Nwangburuka, C. and Oboirien, R. (2017) Origins, Roles and Fate of Organic Acids in Soils: A Review. South African Journal of Botany, 108, 393-406. https://doi.org/10.1016/j.sajb.2016.09.002

[34] An, Y., Zhou, P., Xiao, Q. and Shi, D. (2014) Effects of Foliar Application of Organic Acids on Alleviation of Aluminum Toxicity in Alfalfa. Journal of Plant Nutrition and Soil Science, 177, 421-430. https://doi.org/10.1002/jpln.201200445

[35] Bolan, N.S., Naidu, R., Mahimairaja, S. and Baskaran, S. (1994) Influence of Low-Molecular-Weight Organic Acids on the Solubilization of Phosphates. Biology and Fertility of Soils, 18, 311-319. https://doi.org/10.1007/BF00570634

[36] Jones, D.L., Darrah, P.R. and Kochian, L.V. (1996) Critical Evaluation of Organic Acid Mediated Iron Dissolution in the Rhizosphere and Its Potential Role in Root Iron Uptake. Plant and Soil, 180, 57-66. https://doi.org/10.1007/BF00015411

[37] Pérez-Labrada, F., Benavides-Mendoza, A., Juárez-Maldonado, A., Solís-Gaona, S. and González-Morales, S. (2020) Organic Acids Combined with Fe-Chelate Improves Ferric Nutrition in Tomato Grown in Calcisol Soil. Journal of Soil Science and Plant Nutrition, 20, 673-683. https://doi.org/10.1007/s42729-019-00155-3

[38] Wani, M.A. (2012) Oxalic Acid Effect on Potassium Release from Typical Rice Soils of Kashmir. Communications in Soil Science and Plant Analysis, 43, 1136-1148. https://doi.org/10.1080/00103624.2012.662562

[39] Jalali, M. and Zarabi, M. (2006) Kinetics of Nonexchangeable-Potassium Release and Plant Response in Some Calcareous Soils. Journal of Plant Nutrition and Soil Science, 169, 196-204. https://doi.org/10.1002/jpln.200521772

[40] Oral, A. and Uygu, V. (2018) Effects of Low-Molecular-Mass Organic Acids on P Nutrition and Some Plant Properties of Hordeum vulgare. Journal of Plant Nutrition, 41, 1482-1490. https://doi.org/10.1080/01904167.2018.1458866

[41] Andrade, F.V., Mendonça, E.S., Silva, I.R. and Mateus, R.F. (2007) Dry Matter Production and Phosphorus Accumulation by Maize Plants in Response to the Addition of Organic Acids in Oxisols. Communications in Soil and Science and Plant Analysis, 38, 2733-2745. https://doi.org/10.1080/00103620701662976 